sil

(a)

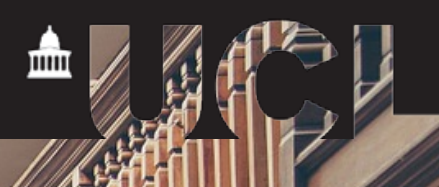

Research Paper Series: 3/2011

8

31

$\lim _{\rightarrow \infty}$

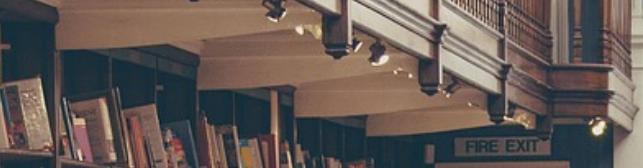

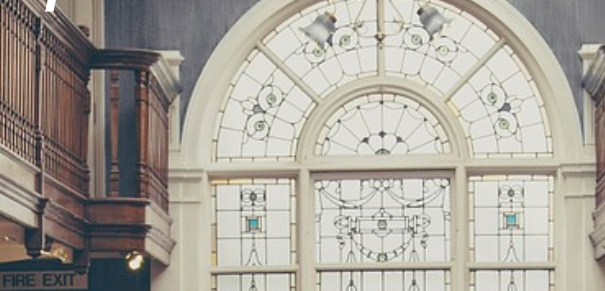

diul 7 an

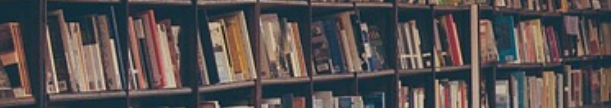

II
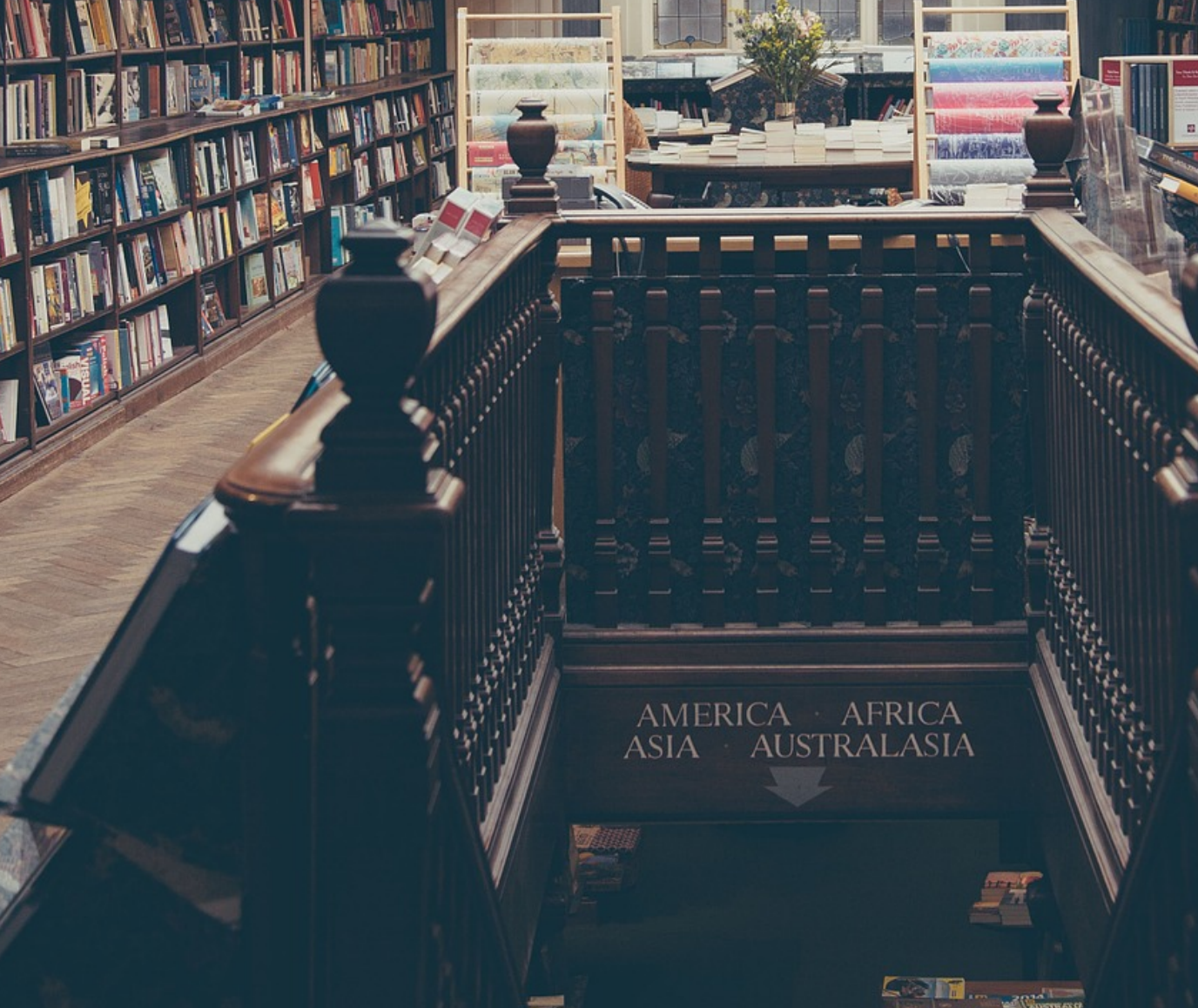

cs and

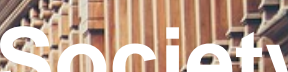

artin (iv) $=$ ind
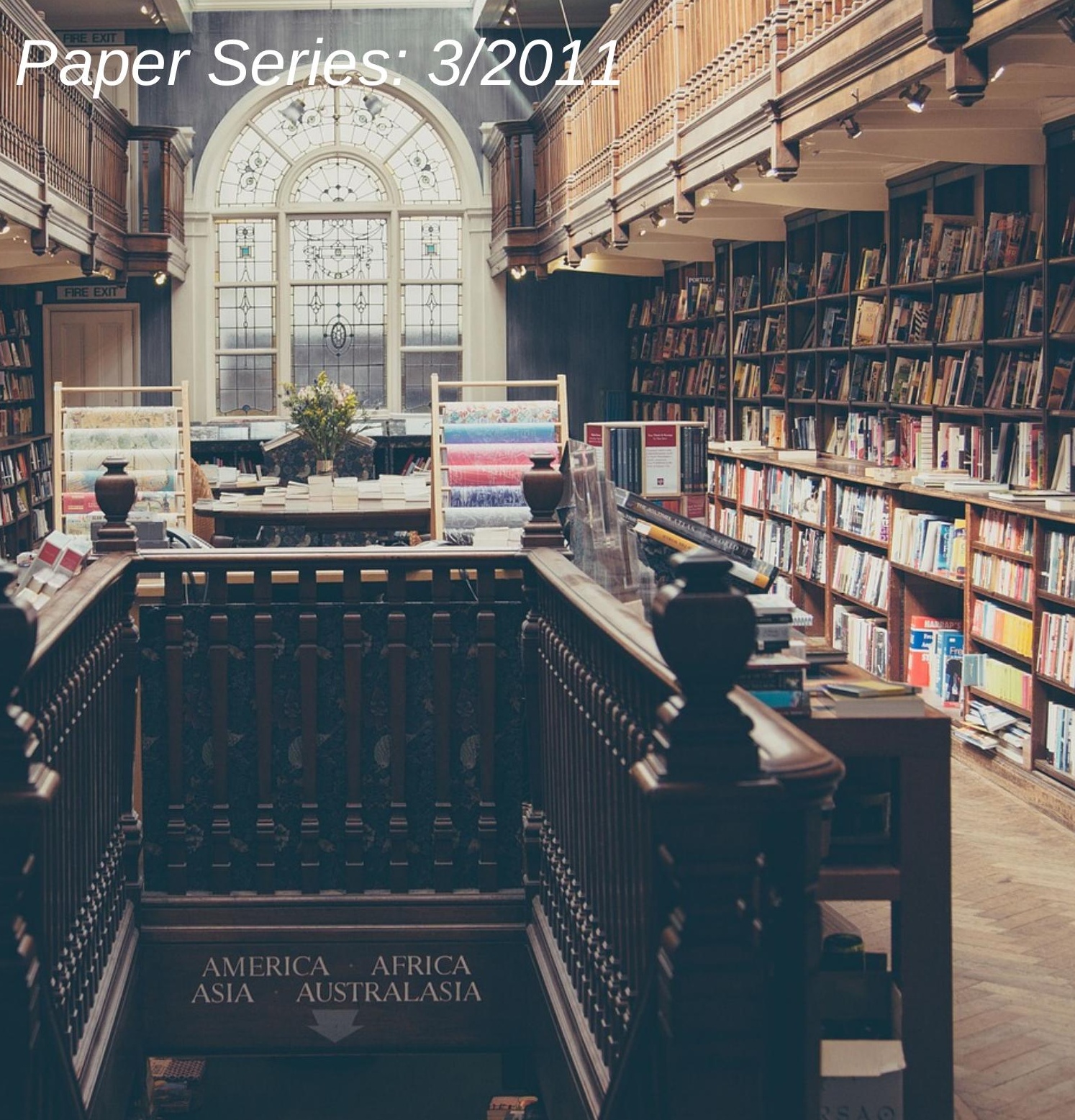

(1) 15$] \frac{2}{d}$

IB
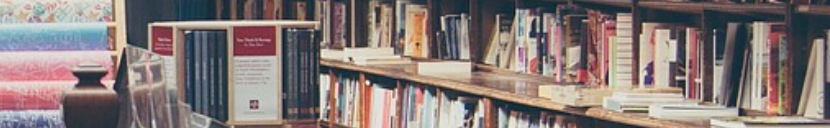

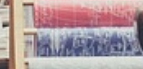
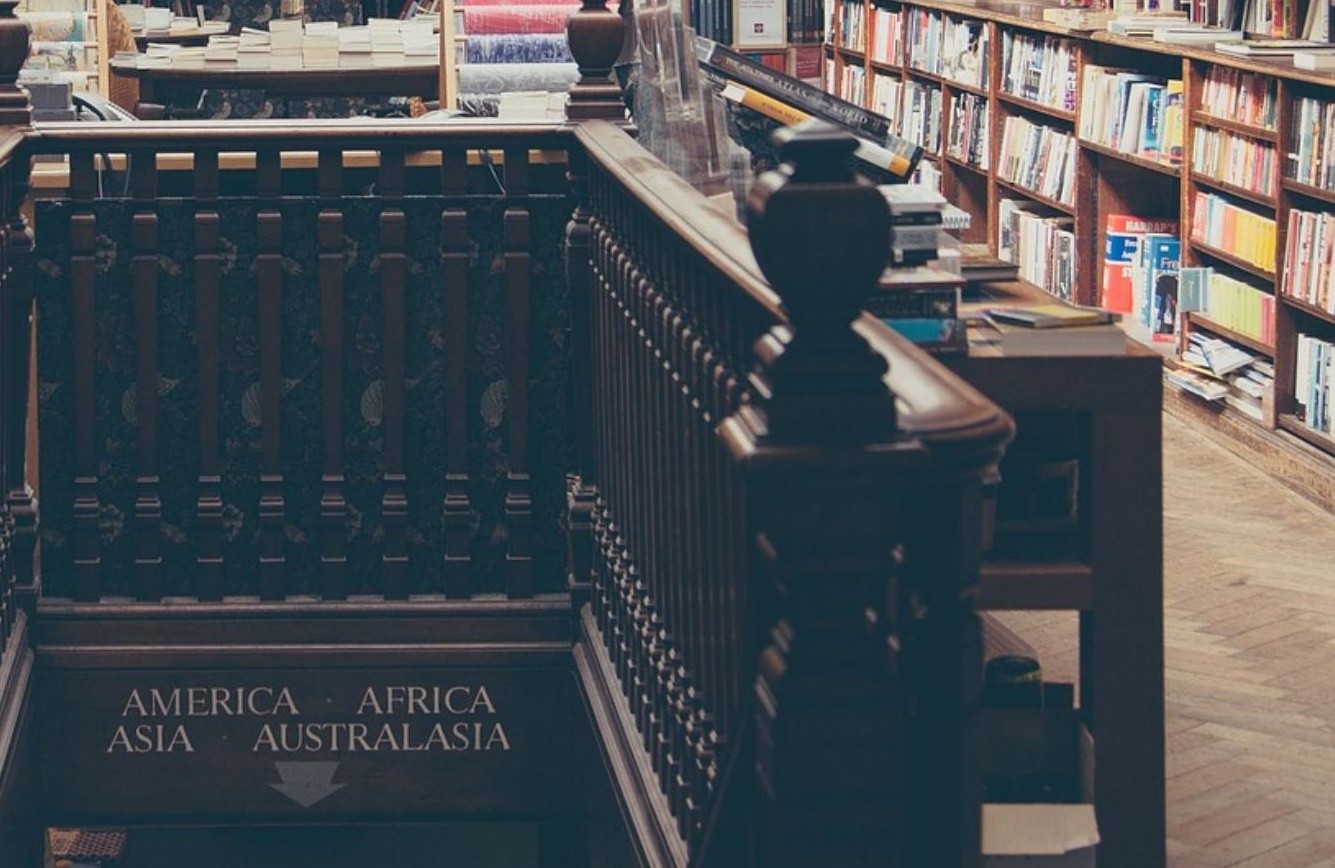

AMERICA - AFRICA
ASIA AUSTRALASIA

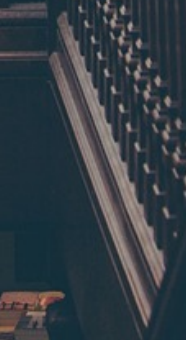

Competition Law Remedies. In Search of a Theory

Professor loannis Lianos 


\section{Centre for Law, Economics and Society CLES}

Faculty of Laws, UCL

Director: Dr loannis Lianos

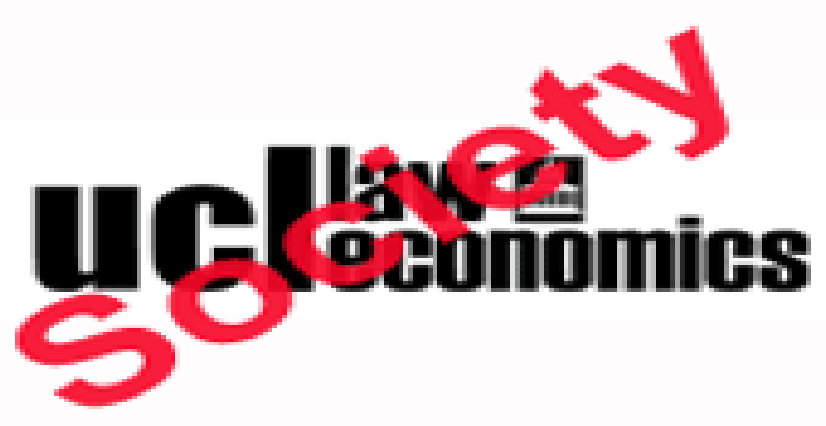

CLES Working Paper Series

$3 / 2011$

Competition Law Remedies. In Search of a Theory

Ioannis Lianos

April 2011 
This is a pre-edited version of a chapter forthcoming at loannis Lianos and Daniel D. Sokol, The Limits of Competition Law (forth. Stanford University Press, 2012). 


\title{
Competition Law Remedies: In Search of a Theory
}

\author{
loannis Lianos*
}

\section{Introduction}

For a long time, the debate on Article 102 TFEU has focused on the interpretation of the different constitutive elements of the abuse of a dominant position, the opposition between a "form-based" and an "effects-based" approach, and the definition of the scope of the special responsibility of dominant firms to preserve competition. The issue of remedies has been relatively neglected. The coming of age of European Union (EU) competition law on Article 102 TFEU with a number of decisions on high profile abuse of dominance cases involving important international undertakings and the adoption of complex remedial schemes has brought the issue of remedies for the abuse of a dominant position to the center of the attention of competition law policy makers, enforcers, and academics. ${ }^{1}$

The Microsoft decision in the United States (US) and in the EU has been the catalyst of this increasing interest on the topic of remedies. There was little suspense over the existence of a dominant position or that of an abuse. The main concern expressed related to the remedies that were adopted in this case. ${ }^{2}$ Some authors argued that these remedies failed to achieve their objectives. ${ }^{3}$ Other authors were more measured in their judgement. ${ }^{4}$ The Microsoft case did indeed put competition authorities and the courts to the difficult position of engineering a remedy that would achieve a specific market outcome. In the US case, Judge Jackson, of the DC District Court, had ordered the breakup of Microsoft into several different

\footnotetext{
* Reader in European Union Law and Competition Law and Economics, Faculty of Laws, UCL. Director, Centre for Law, Economics and Society; co-director, Centre for Law and Governance in Europe; co-director, Institute of Global Law, Faculty of Laws, UCL. i.lianos@ucl.ac.uk

${ }^{1}$ See OECD, Policy Roundtables: Remedies and Sanctions in Abuse of Dominance Cases, (2006) available at http://www.oecd.org/dataoecd/20/17/38623413.pdf; NICHOLAS ECONOMIDES \& IOANNIS LIANOS, A Critical Appraisal of Remedies in the E.U. Microsoft Cases, 2010 Colum. Bus. L. REV. 346 (2010).

2 For a detailed analysis see Nicholas Economides \& loannis Lianos, The Quest for Appropriate Remedies in the EC Microsoft Cases: A Comparative Appraisal, in MICROSOFT ON TRIAL: LEGAL AND ECONOMIC ANALYSIS OF A TRANSATLANTIC ANTITRUST CASE 393 (Luca Rubini ed., 2010).

${ }^{3}$ Carl Shapiro, Microsoft: A Remedial Failure, 75 ANTITRUST L.J. 739 (2009).

${ }^{4}$ Keith N. Hylton, Remedies, Antitrust Law and Microsoft: Comment of Shapiro, 75 ANTITRUST L.J. 773 (2009); and the articles published in the special issue Symposium: Remedies for Dominant Firm Misconduct, 76 ANTITRUST L.J. 11 et seq., (2009).
} 
companies. ${ }^{5}$ Microsoft's terms (royalties) for the licences to its communication protocols also had to be made attractive so as to increase the number of licensees, relatively few at the beginning of the remedial process. ${ }^{6}$ Microsoft was also asked to perform a number of promotional activities in order to attract new licensees. In the EU case, Microsoft was required to offer an unbundled version of the Windows operating system, without Windows Media Player. The explicit aim of the remedy was to challenge Microsoft's distributional advantage and the implicit aim to lower Microsoft's market share in the operating system market. ${ }^{7}$

These relatively complex and far reaching remedies, in terms of state intervention into the market, raise the issue of the Commission's discretion and the relation between the remedy and the antitrust liability phase in a competition law case. One position is to consider that "[t]he nature of the remedy sought in an antitrust case is often ... an important clue to the soundness of the antitrust claim" (the "if you cannot fix it, it isn't broken" argument). The effectiveness of the remedy would thus be a limit to the extension of the antitrust liability and the scope of Article 102 TFEU. Although it is clear that, in principle, the costs of remedies should not outweigh the consumer benefit they achieve, some contend that plaintiffs employ a sequential information model that addresses one issue at a time. It would be therefore inappropriate to dismiss a case simply because the plaintiff did not identify an adequate remedy. Harry First rightly observes, "it seems inevitable that plaintiffs will refine their case as they learn more in the course of the litigation process," in particular in high tech industries where technological change is so complex and so rapid that there is a need for quick action. ${ }^{9}$

However, I will argue that it would be risky, at the same time, to provide full discretion to the Commission adopt remedies that have a remote link to the scope of the antitrust liability identified. As I will explain in the next section, one should not

\footnotetext{
${ }^{5}$ United States v. Microsoft Corp., 87 F. Supp. 2d 30 (D.D.C. 2000).

${ }^{6}$ William H. Page \& Seldon J. Childers, Software Development as an Antitrust Remedy: Lessons from the Enforcement of the Microsoft Communications Protocol Licensing Requirement, $14 \mathrm{MICH}$. TELECOMM. TECH. L. REV. 77, 114 (2007).

7 See EU Seeks Big Drop in Microsoft Market Share, REUTERS, Sept. 17, 2007, available at http://www.reuters.com/article/idUSL1720058720070917.

${ }^{8}$ Brunswick Corp. v Riegel Textile Corp, 752 F.2d 261, 267 (7th Cir. 1984).

${ }^{9}$ Harry First, Netscape is Dead: Remedy Lessons from the Microsoft Litigation 31 (NYU Law \& Econ. Research Paper Series, Working Paper No. 08-49, 2008), available at http://ssrn.com/abstract=1260803.
} 
separate questions of remedy from questions of liability as proponents of "discretionary remedialism" often do. "Discretionary remedialism" 10 is the "view that courts [in this case we will add competition authorities] have discretion to award the 'appropriate' remedy in the circumstances of each individual case rather than being limited to specific (perhaps historically determined) remedies for each category of causative events." ${ }^{11}$ The third section will attempt to integrate the issue of discretionary remedialism and the distinction between the liability and remedial phase to the broader question of the relation between efficiency, distributive justice on the one hand and corrective justice on the other. The thoughts included in this section are preliminary and are part of some ongoing work by the author. The fourth section will examine the importance of "discretionary remedialism," in particular in the context of antitrust, but also will analyse why it is important to limit its effects. The fifth section will explore the objectives pursued by competition law remedies, in order to show that a coherent theory of competition law remedies is incompatible with a sharp dichotomy between liability and remedy questions. The sixth section (and the Annex) will provide illustrations of the link between the two issues by looking to the past jurisprudence on remedies of the European Commission and the European Courts. The emergence of a remedial proportionality test in EU competition law demonstrates the necessary logical connection between the remedy and the liability phase. The seventh section will explore if, and how, the remedial proportionality test will operate in the context of an "effects-based approach" under Article 102 TFEU.

\section{Discretionary Remedialism and its Necessary Limits}

The legal nature of "remedies" in legal taxonomy has been a matter of controversy and doctrinal speculation. Is it important to distinguish what constitutes a substantive issue from what can be characterized as a remedial issue? Are remedies

\footnotetext{
${ }^{10}$ A term first employed in the context of restitution by Professor Peter Birks, Three Kinds of Objection to Discretionary Remedialism, 29 U.W. AustraliA L. REV. 1 (2000), who was a fervent critic of "discretionary remedialism."

${ }^{11}$ Simon Evans, Defending Discretionary Remedialism, 23 SYDNEY L. REV. 463, 463 (2001). For a general discussion; see Darryn Jenson, The Rights and Wrongs of Discretionary Remedialism, SINGAPORE J. LEGAL STUD. 178 (2003).
} 
related to procedural issues, or should they be distinguished from both substance and procedure? Views of course diverge. Some authors have proclaimed that "there is no law of remedies." ${ }^{12}$ At the same time they acknowledged that remedies "have always been the means by which the abstractions of the substantive law are translated into concrete terms," thus advancing the view that remedies are more a sort of social institution than a proper legal one. ${ }^{13}$ Others defend the thesis that remedies "should be eliminated from our analytical vocabulary-that is from the vocabulary which we use when we mean to be taken seriously and to be understood". ${ }^{14}$ The term remedy is found "chameleonic, for as the context shifts its meaning takes on different colours," for example, "in the medical world, a remedy may be either curative, therapeutic or both." ${ }^{15}$ Undeniably, any attempt to provide a more precise legal definition of the term has faced important conceptual difficulties. One could consider that the term remedy refers to prevention as well as cure for the violation of a right: it is "the action or suit by means of which a right is protected" or "the protection which the action or suit affords." ${ }^{16}$

The linkage of remedies to rights was exemplified by the maxim, ubi jus, ibi remedium, which assumes that rights are legal prerequisites for remedies while, at the same time, a right defines a remedy. We know of course that this thesis is not accurate, as there are rights for which there is no remedy. A different view is that remedies are secondary rights "of instrumental character;" they imply the existence of primary rights that are conferred "for the better protection and enforcement of those other rights and duties whose existence they so suppose." ${ }^{17}$ This approach relies on the existence of a close connection between the substantive right and the remedy. The latter is conceived as a secondary right, superposed to the superstructure of the primary right that has been violated (wrong). Wrongs are violations of primary rights that give rise to secondary rights, whose nature may be sanctioning (preventive) or remedial (reparative). Before a wrong gives rise to a

\footnotetext{
${ }^{12}$ Charles Alan Wright, The Law of Remedies as a Social Institution, 18 U. DET. L.J. 376 , 376 (1955). ${ }^{13}$ Id.

${ }^{14}$ Peter Birks, Rights, Wrongs, and Remedies, 20 OXFORD J. LEGAL STUD. 1, 3 (2000).

${ }^{15}$ Kellis E. Parker, Modern Judicial Remedies: CASes and MATERIals 10 (Little Brown 1975); see also Birks, supra note 14 ("anything that alleviates, eliminates, or prevents can be referred to as a remedy").

${ }^{16}$ Christopher C. Langdell, A Brief SuRvey of Equity JuRISDiction 19 (The Harvard Law Review Association 1904).

17 John Austin, Lectures on Jurisprudence or the Philosophy of Positive LaW 762 (Robert Campbell ed., John Murray 5th ed. 1885).
} 
secondary (remedial) right, it is essential to examine if there is a legal cause of action. The concept of legal cause of action breaks the direct causality chain between primary rights and remedies implied by the maxim ubi jus, ibi remedium. A specific remedy does not necessarily follow the violation of the primary right. The relation between these three concepts has been explained in the following terms:

Primary rights describe a person's initial legal entitlement. Secondary rights describe the remedies to which he is entitled if the primary right is violated. When this violation takes place (for example, a tort is committed or contract breached), we talk of there being an injustice and a legal cause of action. Causes of action describe those events which consist in the violation of private law rights, or, to use different words of my own, primary injustices. Remedies constitute the law's response to such events and describe a secondary level of entitlement, substituted by the law for the first. Causes of action provide us with answers to the question when legal relief is to be given; remedies answer the question how it is to be given. ${ }^{18}$

The reference to "causes of action" provides an intermediary step between primary rights and remedies, thus making clear that the two concepts should be distinguished from each other. The criteria used to define the violation of the primary right are not similar to those giving birth to the secondary right. The two can indeed operate independently of one another. The violation of a primary right may yield a whole range of responses: different types of secondary rights, which do not necessarily have any logical connection to the specific wrong, or violation of the primary right. They might give rise to substitutionary remedies, such as damages or fines, even if these do not correspond to a specific type of wrong committed and might indeed be employed for various forms of violation of the primary right: "as a jellyfish trails its tentacles in the warm sea, so from many civil wrongs dangle a plurality of remedial strings." ${ }^{19}$ Law treats liability and remedy as legally distinct. At the same time, employing the terminology "causes of action" indicates that the concept of remedy should not be confined to "forms of action," that is legal claims

\footnotetext{
${ }^{18}$ Kit Barker, Rescuing Remedialism in Unjust Enrichment Law: Why Remedies Are Right, 57 CAMBRIDGE L.J. 301, 319 (1998).

${ }^{19}$ Birks, supra note 14 , at 7 .
} 
that are channelled through (and understood by reference to) prescribed forms of action. $^{20}$

Alternatively, it is possible to consider that a remedy is "an action, or the law's configuration of the actionability of a claimant's story" and thus to establish a strict separation between the concept of remedy and that of the violation of the primary right or wrong committed. ${ }^{21}$ The term remedial will be used in this case essentially as a synonym of discretionary. ${ }^{22}$ This position will conceptualize remedies as a specific form of judicial decision-making. I will use the terminology of service judicial acts ("actes juridictionnels de service"), as opposed to declaratory judicial acts, whose main function is to acknowledge the violation of the primary right. The remedies will be in the decision-maker's discretion according to the criteria of appropriateness. Liability and remedy thus would be separate concepts where, "liability triggers the court's discretion in the matter of the remedy." ${ }^{23}$ Rejecting the existence of a connection between primary rights and remedies, the theory of discretionary remedialism tolerates only procedural limits on remedial discretion. This could increase uncertainty and unpredictability as to the nature and form of the remedy.

Uncertainty and unpredictability are certainly to be avoided with regard to the areas of law that rely on private governance (i.e., contracts and torts), where the aim is to facilitate the exercise of private choice in the most efficient way. ${ }^{24}$ But is predictability and certainty necessary to the same extent within a regime of public governance, such as competition law? For example, it is possible to argue that greater predictability of the competition law remedy might facilitate the breach of the primary right, as it would be possible for the undertaking to calculate precisely the costs and benefits of the violation and therefore to make sure that the breach of the primary right is profitable. However, contrary to what might happen in regimes of private governance, ${ }^{25}$ a breach of the primary right can never be efficient in

\footnotetext{
${ }^{20}$ Barker, supra note 18 , at 312.

${ }^{21}$ Birks, supra note 14 , at 10.

22 Id. at 17.

23 Id. at 23.

${ }^{24}$ On the classification of the legal system in regimes of private and public governance, see ANTHONY OGUS, COSTS AND CAUTIONARY TALES: ECONOMIC INSIGHTS FOR THE LAW 71-86 (2006).

${ }^{25}$ For example, the breach of a contract might be efficient because the profit of the breach would exceed the profit from completion of the contract. See, for instance, Charles J. Goetz \& Robert E. Scott, Liquidated Damages, Penalties and the Just Compensation Principle: Some Notes on an
} 
competition law, as efficiency is one of the criteria for defining the existence of a breach. Remedial discretion and the consequent unpredictability of the remedy are therefore tolerated, as long as it is within acceptable limits from the point of view of the rule of law. Discretion will be constrained by rules, but these rules do not provide a stable basis for predicting legal outcomes and the way these rules apply owe much to variable and discretionary factors.

There are inherent risks in adopting a strict separation of primary rights and remedies, and the strong discretionary remedialism that ensues. First, remedies have a purpose and this purpose is inevitably defined, at least, with regard to the primary right that has been violated or the wrong that has been committed. It is impossible to totally disconnect the two, even if they are subject to different criteria. Second, the requirements of the "rule of law" are not only procedural but also substantive. For example, the concept of proportionality, a justiciable expression of the rule of law, has both a procedural and a substantive nature. The latter is intrinsically linked to the scope of the primary right. It follows that there must be some degree of logical connection between primary rights or wrongs and remedies, without that, however, leading to question the existence of two separate legal categories. As Kit Barker rightly observes:

the way in which the primary right is described tends to suggest a certain logical range of responses to its violation: to adumbrate a range of viable secondary rights ... The criteria which set up the primary right none the less remain distinct from those which weigh upon a court's decision how to respond, when it is violated. ${ }^{26}$

In conclusion, the theoretical distinction between rights (or wrongs) and remedies should not lead one to conceptualize one category in isolation from the other. This chapter advocates a reflexive relationship between primary and secondary rights (rights and remedies) ${ }^{27}$. Such an approach will facilitate the understanding of the meaning and the purpose of the right that has been violated:

Enforcement Model and A Theory of Efficient Breach, 77 Columbia L Rev 554 (1977) and the discussion in RICHARD A. POSNER, ECONOMIC ANALYSIS OF LAW 120 (2003).

${ }^{26}$ Barker, supra note 18 , at 320.

${ }^{27}$ ld. at 323. 
Just as the way the primary right is defined has an effect upon the range of responses which can logically attend its violation, so too, the selection of a particular response contributes to our impression of the meaning and the purpose of the right violated. . . . [W]e judge the nature and power of a primary right by observing the way courts react to its violation in their selection of remedy or-which is the same thing-in their allocation of secondary rights. $^{28}$

Furthermore, this approach implies that the limits to discretionary remedialism should not only be of procedural nature but should also relate to the substance of the primary right.

\section{The Liability/Remedy distinction as an expression of the relationship} between economic efficiency/distributive justice and corrective justice

The question about discretionary remedialism can also be integrated into the broader framework of the relationship between economic efficiency and corrective justice or the relation between distributive justice and corrective justice. We will start with a definition of what each concept entails. The debate has been virulent in the area of torts. Competition law can be perceived as a special case of economic tort, therefore the different positions in this debate could be relevant to our analysis.

For the tenants of economic efficiency as wealth maximization, the concepts of economic efficiency and corrective justice are collapsed. If the aim of the legal system is to promote wealth maximization, this objective will transcend the remedies phase as well. ${ }^{29}$ This duty to act in conformity to the principle of wealth maximization could potentially confer an important remedial discretion, as it would be possible to promote through the adoption of remedies any measure that would achieve

\footnotetext{
${ }^{28} / d$.

${ }^{29}$ Richard A. Posner, The Concept of Corrective Justice in Recent Theories of Tort Law, $10 \mathrm{~J}$. Legal Stud. 187, 201 (1981) (noting that "in [the economic theory of law], laws is a means of bringing about an efficient [in the sense of wealth maximizing] allocation of resources by correcting externalities and other distortions in the market's allocation of resources). The idea of rectification in the Aristotelian sense is implicit in this theory". For a criticism of this view of the Aristotelian theory of corrective justice, see Bill Shaw\& William Martin, Aristotle and Posner on Corrective Justice: The Tortoise and the Hare, 9 Bus. ETHICS Q. 651 (1999).
} 
maximization of wealth, without any specific limit imposed by corrective justice ${ }^{30}$ For example, it is possible to adopt remedies that impose a better, from a wealth maximization perspective, competitive equilibrium than the one existing prior to the occurrence of the specific illegal practice. For example, the counterfactual to compute damages in case of an exclusionary abuse of dominant position may be that of perfect competition or an oligopoly equilibrium in which the competitors of the liable firm obtain profits and set up the investments to properly serve the market, whereas the situation, prior to the violation was that of a dominant firm with a competitive fringe equilibrium. It is only if there is a presumption that the pretransactional situation is the most efficient one, from a wealth maximization perspective, that the principle of corrective justice could be constrained in modifying the pre-transactional competitive equilibrium. In an economic efficiency inspired legal framework, it would be theoretically possible to refuse to adopt a remedy. Thus, the remedy would ignore corrective justice, if the result of such implementation of corrective justice would be to reduce the aggregate total welfare.

Deterrence (as a facet of wealth maximization) also should be added. Economic analysts of law view tort law's function as mainly a deterrent device directed at potential tortfeasors with the view to ensure that the individuals responsible for the tort (specific deterrence), but also any other potential tortfeasor (general deterrence), would be given sufficient disincentive to be discouraged to engage in the activity in the future. ${ }^{31}$ Penalties should thus be sufficient to induce offenders to internalize the full social costs of their behavior (the internalization thesis), which supposes that if there is perfect detection and no social cost of imposing punishment, the optimal sanction will be equal to the net social (efficiency) loss post violation (compared to the situation prior the violation). ${ }^{32}$

The penalty should be equal to the net harm to everyone but the offender. ${ }^{33}$ For cartels, the optimal penalty would be equal to the deadweight welfare loss plus the

\footnotetext{
${ }^{30}$ It is interesting here to compare the almost unlimited discretion for imposing remedies under this conception with the limited scope of the liability if ones uses the concept of causation. See Steven Shavell, An Analysis of Causation and the Scope of Liability in the Law of Torts, 9 J. LEGAL STUD. 463 (1980).

${ }^{31}$ The issue is more complicated in competition law (as in all areas of commercial law) as one should also examine the question of the efficient allocation or mix of deterrence between the corporation and individuals acting on its behalf.

${ }^{32}$ Gary S. Becker, Crime and Punishment: an Economic Approach, 76 J. POL. ECON. 169 (1968).

${ }^{33}$ William M. Landes, Optimal Sanctions for Antitrust Violations 50 U. Chi. L. Rev. 652, 656 (1983).
} 
wealth transfer to the cartel from purchasers. This penalty would deter only those instances of the offense in which the deadweight welfare loss exceeds any savings in production costs to the cartel. Accordingly, if the enforcement costs are positive and the probabilities of detection and punishment are less than perfect, optimal penalties should exceed the social (efficiency) cost of the violation so that they correspond to the efficiency loss caused. The minimum punishment for deterrence to work will be equal to the expected gain from the violation (including interest) multiplied by the inverse of the probability of the punishment being effectively imposed. The idea behind this is that the penalty must be sufficient to render the expected value of the violation equal to zero. By imposing this cost, the offense will be deterred. The internalization approach limits theoretically the discretion of the authorities to impose penalties, if it will lead to a less satisfactory, from an efficiency perspective, equilibrium than that existing prior to the violation.

At the same time, if the aim is to ensure that the tortfeasor will be given sufficient disincentive to be discouraged from engaging in the activity in the future, the expected value of the violation should be negative (pure deterrence model). As Gardner rightly explains:

[i]ts success in securing that actual tortfeasors bear the losses they have already wrongfully occasioned - its corrective success - is important mainly as a means of securing that, in future, fewer torts are committed, with the result that there will be fewer occasions, in future, for actual tortfeasors to bear the losses they wrongfully occasioned. ${ }^{34}$

In this case, it would make sense to include all possible losses, including those of the competitor's of the offender that were, for example, foreclosed from the market, for the long term effects persisting after the practice has been terminated, or upstream suppliers for lost sales, which, as Hovenkamp notes, are "potentially unlimited" losses. ${ }^{35}$ Of course, increased sanctions and excessive penalties also may deter efficient conduct and generate overinvestment in compliance, which might be inefficient. However, for the tenants of the pure deterrence model, that should not be

\footnotetext{
${ }^{34}$ John Gardner, What is Tort Law For? Part 1. The Place of Corrective Justice, 30 L. \& Phil. 1, 30 (2011).

${ }^{35}$ Herbert Hovenkamp, Antitrust's Protected Classes, 88 MICH. L. REV. 1 (1989).
} 
a major issue, because of the future consequence of deterring harmful conduct (and therefore its future positive wealth maximization effects). ${ }^{36}$ The boundaries between efficiency and distributive justice are blurred if the welfare of the victims is given more weight than that of the antitrust violators.

Deterrence also might be an objective of corrective justice. One could thus distinguish between two forms of deterrence: deterrence as wealth maximization and deterrence as a moral requirement for corrective justice to work effectively (thus a form of efficiency independent from wealth maximization). As Gardener forcefully explains, there is a distinction to be made between the moral content of corrective justice and the legal principle of corrective justice:

[the legal principle of corrective justice] is supposed to be efficient at securing that people conform to certain . . . moral norm of corrective justice . . As well as correcting torts that have already been committed, this legal principle is apt systematically to deter the commission of torts that have not yet been committed. $^{37}$

Thus, deterrence has a role to play even for societies valuing only the moral principle of corrective justice and rejecting efficiency as a normative value (deterrence-based corrective justice approach). As with the pure deterrence wealth maximization model, there seem to be few limits to the discretion of authorities to impose far reaching remedies.

The distinction between distributive justice and corrective justice can be explained by the different emphasis given in each theory of justice. Distributive justice describes a morally required distribution of shares of resources among members of a given group, either because of their membership to that group or in accordance with some measure of entitlement which applies to them in virtue of their membership. This is understood dynamically, that is across various situations in the specific jurisdiction. Corrective justice describes a moral obligation of repairing the harm caused to another person: it is thus more static as it concerns the specific

\footnotetext{
${ }^{36}$ Wouter P. J. Wils, Optimal Antitrust Fines: Theory and Practice, 29 WORLD COMPETITION 183 (2006).

${ }^{37}$ Gardner, supra note 34, at 26, 29.
} 
transaction. Rights and duties in distributive justice are "agent-general", while in corrective justice, "they are agent-specific." 38

Corrective justice may be perceived as both an action triggered and limited in scope to a specific transaction. The remedy is measured in terms only of the transaction, without regard to the extra-transactional material holdings of the parties, and as a "substantive principle of liability and remedy", which "requires those who impose wrongful losses on others to repair those losses." ${ }^{39}$ What counts as a wrongful loss is not, however, something that is decided by corrective justice. On certain accounts, it is distributive justice that "sets the baseline against which wrongful costs are measured", distributive justice providing information on the set of material holdings that serve as the status quo against which the wrongful costs are measured. ${ }^{40}$ It follows that corrective justice is the "remedial arm" of distributive justice. $^{41}$ If this is true, one could wonder on the exact role of corrective justice and the reasons it merits to be held apart from distributive justice.

The relationship between the two concepts has been put either in terms of normative priority or independence. ${ }^{42}$ The priority view conceives that distributive justice is normatively prior to corrective justice. The consequence is that corrective justice will be instrumental to distributive justice and its normative character will derive entirely from it. The duty to repair, therefore, would be granted exclusively on distributive justice claims. If distributive justice and corrective justice have completely coextensive domains, then one should reject corrective justice for the reason that distributive justice is logically prior, insofar as "there must be a distribution relative to which loss and compensation are measured." ${ }^{43}$ As Benson notes, unless claims of corrective justice are grounded on independent, non-distributive, measures of

\footnotetext{
${ }^{38}$ See Stephen Perry, On the Relationship between Corrective and Distributive Justice, in OXFORD ESSAYS IN JURISPRUDENCE 237, 238 (Jeremy Horder ed., 4th series, Oxford Univ. Press 2000); Dennis Klimchuk, On the Autonomy of Corrective Justice, 23 OXFORD J. LEGAL STUD. 49 (2003).

${ }^{39}$ Klimchuck, supra note 38, at 52.

40 ld.

${ }^{41} / d$. at 53.

42 Steven Walt, Eliminating Corrective Justice, 92 VA. L. REV. 1311 (2006).

${ }^{43}$ Larry A. Alexander, Causation and Corrective Justice: Does Tort Law Make Sense?, 6 L. \& PHIL. 1, 7 (1987).
} 
entitlement, corrective justice will inevitably collapse to distributive justice. ${ }^{44}$ However, as the same author notes,

what is to preclude the injury party from claiming that the infringement should be viewed simply as a redistribution of holdings in accordance with the same or a competing criterion of distribution? If the injury party can coherently frame the dispute in this way, the correction of the infringement should also properly be characterized as an act of distributive justice, seeing that it can be viewed as a decision made between two competing distributive claims. ${ }^{45}$

The wrongdoer thus could claim a different distributive claim, based, for example, on an alternative distributive measure (the so called Robin Hood defense). The only possibility, according to the same author, to avoid a counter-claim based on another distributive justice criterion is to presume that the distribution prior the commitment of the wrong was just and thus bar the injuring party from framing the violation "in terms of a competing distributive claim." ${ }^{46}$ However, it might be profoundly unjust and arbitrary to confer this presumption of validity to the pre-transactional allocation rather than to the new arrangement. ${ }^{47}$ In conclusion, corrective justice is independent from distributive justice only if one assumes that the pre-transactional distribution is just. A similar conclusion is reached by Jules Coleman when he notes that "if corrective justice provides moral reasons for repairing a loss, then the underlying claims sustained by corrective justice must themselves express requirements of distributive justice [...] This relationship appears to rob corrective justice of its moral independence." 48

This debate is of particular interest for our discussion of discretionary remedialism. If corrective justice (the remedy) is derivative of distributive justice (liability), the assumption being that the pre-transactional allocation of entitlements is just, then, the remedy cannot go further than restoring the pre-transactional situation. It cannot modify it to an allegedly superior distributive justice measure. In other

\footnotetext{
${ }^{44}$ Peter Benson, The Basis of Corrective Justice and its Relation to Distributive Justice, 77 IowA L. REV. 515 (1992).

${ }^{45}$ Id. at $530-31$.

${ }^{46}$ Id. at 531.

${ }^{47}$ Id. at 532.

48 JULES L. COLEMAN, RISKS AND WRONGS 348 (Cambridge University Press 1992).
} 
words, the pre-transactional distributive justice entitlement is the only measure of the remedy.

On the contrary, proponents of the independence view advocate that corrective justice and distributive justice are normatively independent, in particular if an obligation of repair could apply without regard to the satisfaction of the demands of distributive justice. Steven Perry explains:

Corrective justice is a general moral principle that is concerned, not with maintaining a just distribution, but rather with repairing harm. Individuals can be harmed in a number of different ways, and corrective justice accordingly protects a number of different kinds of interest and entitlement, Distributive justice often contributes to the legitimacy of an entitlement that corrective justice protects, and in that sense there is a normative connection between the two. But corrective justice does not protect the entitlement qua distributive share, and its purpose is not to maintain or preserve a distributive scheme as such. Rather it protects a legitimate entitlement because interference with the entitlement harms the entitlement-holder. In that sense, corrective and distributive justice are conceptually independent. ${ }^{49}$

This dissociation of corrective justice and distributive justice does not mean that corrective justice does not have distributive consequences but only that the preservation of distributive claims is not part of its purpose. The idea is that while corrective justice protects legitimate entitlements, this is not done because of a distributive justice consideration but because of the duty to repair harm imposed by corrective justice. The concept of harm thus dissociates the concept of corrective justice from that of distributive justice. Perry observes that:

(t)he moral focus of the victim's claim is the harm she has suffered. She is saying: you harmed me, and therefore you have a moral obligation to compensate me. The injurer responds with the argument that, distributively speaking, it would be better if he did not have to pay compensation. At most we

\footnotetext{
${ }^{49}$ Perry, supra note 38 , at ??.
} 
have two distinct kinds of moral claims which must be balanced against one another. $^{50}$

The concept of harm responds to the inadequacy, according this view, of applying the concept distributive justice to momentary states, for the reason that distributive justice theories give rise to "great deal of indeterminacy," as they operate through institutions and over time, that is, according to abstract and long-term patterns. ${ }^{51}$ In contrast, corrective justice creates duties to repair that apply at particular moments and thus is normatively independent of distributive justice. Nevertheless, even if the concept of corrective justice is perceived as independent from that of distributive justice, the duty to repair is limited by the "harm" incurred by the injured party. It would not be thus possible to completely dissociate the remedy from the liability phase, as it is in the latter one that harm is defined.

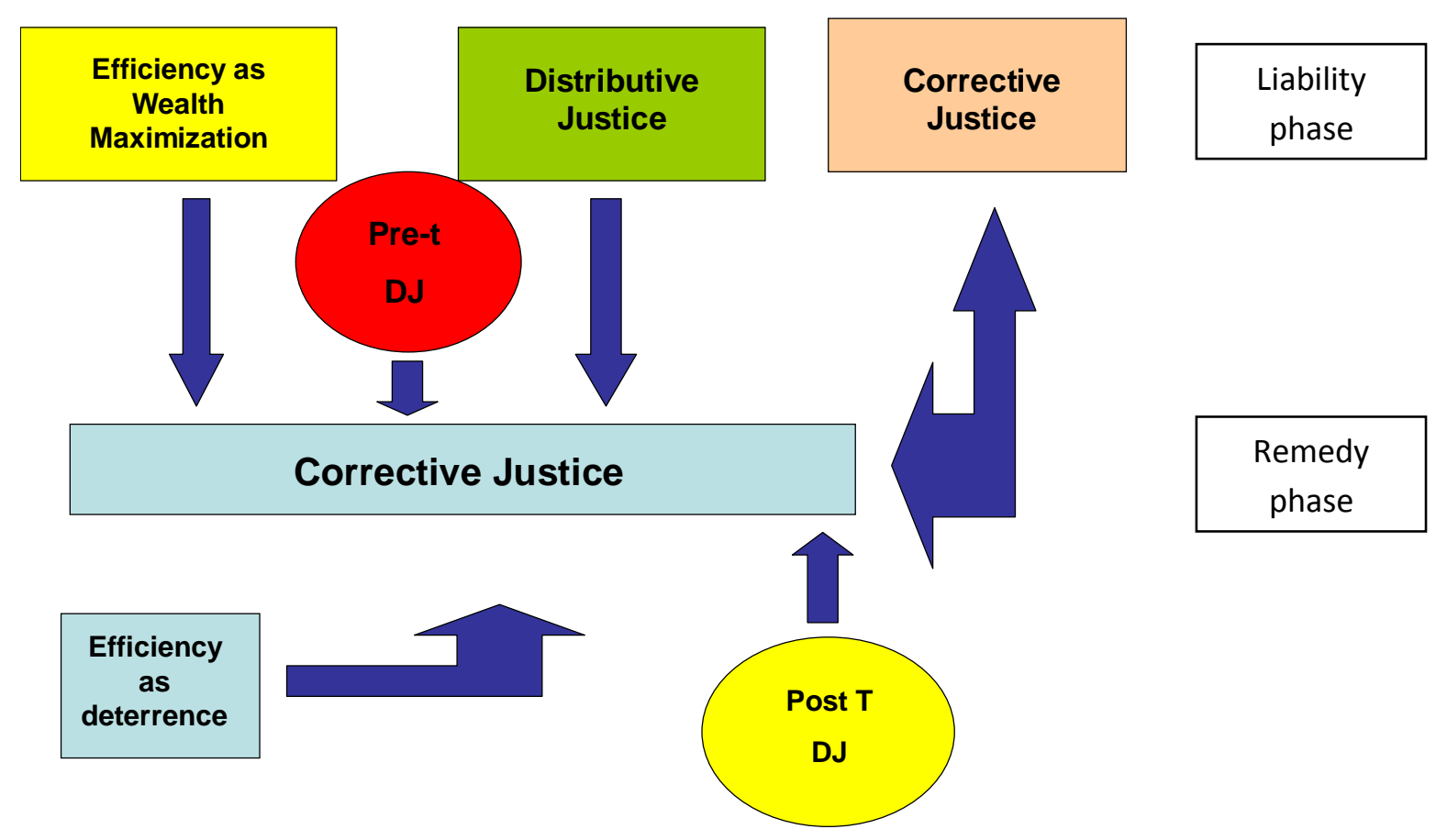

In conclusion, it is only if one adopts a pure deterrence wealth-maximization view or a deterrence-based corrective justice view that discretionary remedialism would be more pronounced. Having discussed the relation between the liability and the

\footnotetext{
50 Id. at 259.

51 Id. at 246.
} 
remedy phases and the interaction between the principles of efficiency as wealth maximization, corrective justice and distributive justice, I will now turn to the aims pursued by competition law remedies.

\section{The Aim of Competition Law Remedies}

Competition law remedies are adopted with the principal aim to restore competition in the market. ${ }^{52}$ This includes first the "micro" goals of putting the infringement to an end, compensating the victims, ${ }^{53}$ and curing the particular problem to competition, but also the "macro" goal of putting incentives in place "so as to minimize the recurrence of just such anticompetitive conduct.".54 This study adopts a broader view of the concept of remedies than Council Regulation 1/2003 on the implementation of the rules on competition laid down in Articles 101 and 102 TFEU $^{55}$ According to Article 7 of Regulation 1/2003, the aim of competition law remedies is "to bring the infringement effectively to an end." Remedies should therefore be distinguished from sanctions against undertakings, as the latter aim to punish the infringer and to provide compensation to victims or society in general. ${ }^{56}$ This distinction does not adequately take into account that both sanctions and remedies affect the incentives of the wrongdoers' in their future behavior on the market and thus may lead to restore competition. Remedies perform different objectives, such as stopping the illegal conduct and preventing its recurrence, restoring competition, deterrence, providing just compensation or disgorgement of illicit profits. This overall approach may provide a more useful analytical framework for analyzing the effect of competition law on the specific market. Furthermore, the restrictive position adopted

\footnotetext{
52 See A. Douglas Melamed, Afterword: The Purposes of Antitrust Remedies, 76 ANTITRUST L.J 359 (2009).

53 Taking illegal gains away from the law violators and "restore those monies to the victims" constitutes a principal goal of competition law remedies. Robert Pitofsky, Antitrust at the Turn of the Twenty-First Century: the Matter of Remedies, 91 Geo. L.J. 169, 170 (2002).

${ }^{54}$ Eleanor M. Fox, Remedies and the Courage of Convictions in a Globalized World: How Globalization Corrupts Relief, 80 Tul. L. Rev. 571, 573 (2005).

${ }_{55}$ Council Regulation No. 1/2003, 2003 O.J. (L 1/1) (EC). See also, on the distinction between remedies and sanctions, OECD, Remedies and Sanctions in Abuse of Dominance Cases 18 (2006), available at http://www.oecd.org/dataoecd/20/17/38623413.pdf, "[t]ypically, remedies aim to stop a violator's unlawful conduct, its anticompetitive effects, and their recurrence, as well as to restore competition. Sanctions are usually meant to deter unlawful conduct in the future, to compensate victims, and to force violators to disgorge their illegal gains."

${ }^{56}$ See also, OECD, supra note 55.
} 
by Regulation 1/2003 concerns public enforcement and does not take into account the emerging role of private enforcement in EU competition law.

Remedies seek generally to restore "the plaintiff's rightful position, that is, to the position that the plaintiff would have occupied if the defendant had never violated the law" or "to restore the defendants to the defendant's rightful position, that is, the position that the defendant would have occupied absent the violation." 57 In other words, remedies are a cure to a "wrong" the plaintiff committed, "in contravention of some legally-recognized right of the plaintiff's" 58 or of the category of right-recipients that the legislator intended to protect. The wrong of the defendant gives rise to the enforceable right of the plaintiff (or the protected category) to impose on the defendant a correlative duty to stop the illegal behavior, pay damages, make restitution, or adopt a specific behavior. Article 7 of Regulation 1/2003 does not oppose this conceptualization of remedies, as it links the adoption of a remedy to the end of the infringement, a concept that might be understood narrowly, the termination of the illegal conduct, but also, more broadly, as outcome-oriented, thus requiring the reversal of the effects of the illegal conduct.

An important aspect in the definition of remedies is therefore to determine who would be the beneficiary of this right. In other words, the protected category retains the right to impose a correlative duty to the defendant. We will assume that the protected category for competition law remedies is the consumers of the relevant market harmed by the "wrong" committed by the defendant. ${ }^{59} \mathrm{~A}$ wider perspective would be to consider that the protected category consists of the "broader public" deriving benefits from the principle of competition, allegedly jeopardized by the practices of the dominant firm. ${ }^{60}$

\footnotetext{
${ }^{57}$ Douglas Laycock, Modern American Remedies: CASES AND Materials 2 (Little Brown 1994).

${ }^{58}$ Michael Tilbury, Michael Noone, \& Bruce Kercher, REMEDIES: COMMENTARY AND MATERIALS 1 (LBC Information Services 3d ed. 2000).

${ }^{59}$ In this case, consumer welfare or consumer sovereignty will be proxies of consumer harm.

${ }^{60}$ See the Opinion of AG Kokott in Case C-8/08 T-Mobile Netherlands BV and Others [Feb. 19 2009] paras. 58, 71 defending the view that the objective of EC competition law is to "protect competition as such" because this is of benefit, not only for consumers but for "the public at large." In Case C-8/08 TMobile Netherlands BV and Others [June 4, 2009] para. 38, the Court of Justice of the EU accepted that "Article $81 \mathrm{EC}$, like the other competition rules of the Treaty, is designed to protect not only the immediate interests of individual competitors or consumers but also to protect the structure of the market and thus competition as such" but did not adopt the position of AG Kokott with regard to the ultimate beneficiaries of the principle of competition, thus suggesting that a possible interpretation of the aims of EC competition law is the avoidance of a long-term consumer harm.
} 
Whichever perspective is chosen, "restoring competition" should not be interpreted as reaching perfect competition (or free competition if one takes a deontological perspective), which is practically unattainable, and in some cases a normatively undesirable objective from a public policy perspective. ${ }^{61}$ The remedy aims to restore the market that would have existed in the absence of the conduct found illegal, that is, what is commonly called the "but for" market conditions.

Competition law remedies list also a prophylactic objective. Threy are to "ensure that there remain no practices likely to result in monopolization in the future. $^{, 62}$ This is certainly a difficult enterprise that requires from the courts a guessing exercise linked to a counterfactual analysis of the situation in the market with and without the specific competition law violations. This is particularly true in complex and dynamically evolving markets, where static models cannot easily predict the situation that would have existed absent the restraint. It also requires a difficult decision on the appropriate remedy enforcement mechanism, as the judge or the authority should decide on the degree of her involvement (as opposed to market forces or regulatory institutions) in the operation. One could indeed perceive the operation of designing appropriate remedies as being, first of all, a decision over the need for regulatory interference in order to bring the self-correcting forces of the market back to their usual operation as the default mechanism that would adjust the incentives of market actors and therefore the interaction between supply and demand in the specific sector of the economy. Thus, remedies could be (i) setting up conditions for the market to work or (ii) directly influencing or guiding the market.

There are of course different choices that can be made and combined in order to affect the incentives of market actors and restore "competition," defined as the

\footnotetext{
${ }^{61}$ In industries with significant network effects, even in the absence of anticompetitive actions, the natural equilibrium is neither perfect competition nor an egalitarian market structure. Markets with strong network effects, such as the market for operating systems of PCs, are "winner-take-most" markets with significant market share and profits inequality as well as high concentration. Thus, the "but for" world that would have existed in the absence of anti-competitive actions is one of very significant inequality. Attempting to impose the perfectly competitive egalitarian environment of a nonnetwork industry can lead to lower social benefits. See Nicholas Economides, The Economics of Networks, 14 INT'L J. INDUS. ORG. 675 (1996), available at http://www.stern.nyu.edu/networks/Economides Economics of Networks.pdf; Nicholas Economides, \& Fredrick Flyer, Compatibility and Market Structure for Network Goods, Discussion Paper, EC-98-02, Stern School of Business, NYU, available at http://www.stern.nyu.edu/networks/98-02.pdf; and Nicholas Economides, Competition Policy in Network Industries: An Introduction, in THE NEW ECONOMY AND BEYOND: PAST, PRESENT AND FUTURE, (Dennis Jansen ed., 2006), available at http://www.stern.nyu.edu/networks/Economides Competition Policy.pdf. ${ }^{62}$ See U.S. v. Microsoft Corp., 253 F.3d 34, 103 (D.C. Cir. 2001) (citation omitted).
} 
best possible outcome for the consumers of the specific relevant market in terms of price, quality, variety, innovation etc, if one assumes, as does this study, a consumer-driven competition law. First, it is possible to contract out the remedy to other affected market participants by enabling them to sue for the recuperation of the damages suffered because of the conduct found illegal or for more than the damages incurred in order to deter market participants from adopting a similar anticompetitive conduct in the future. Second, it is possible to develop remedies that would affect the discretion of market participants to run their business, in other words affect their autonomy as market participants and consequently their incentives. The latter could be conceived as a continuum ranging from preserving some degree of discretion for market participants (in the case of contractual remedies, such as commitments) to purely non-voluntary schemes, unilaterally imposed by the public authorities. One could also distinguish remedies that relate to the conduct of the market participants and attempt to affect their incentives to adopt a specific form of conduct (by creating disincentives such as fines, or, more brutally, by imposing injunctions, interdictions, conduct remedies) from more intrusive remedies that affect the infringing company's assets (structural remedies) or the management's status (criminal sanctions) and thus produce direct effects within the boundaries of the corporation (hierarchy). ${ }^{63}$

\section{Competition Law Remedies for Violations of Article 102 TFEU}

An empirical analysis of the remedies adopted by the European Commission and the European courts in the enforcement of Article 102 (see Annex) shows that fines constitute the measure that is most frequently used, with conduct remedies being adopted in a small number of cases and structural remedies to even fewer cases (Table 1). Substitutionary remedies, such as fines, are obviously easier to impose and to administer than the more complex, generally, conduct remedies. The novelty of the competition law issues that arose in the liability phase of the decisions have

\footnotetext{
${ }^{63}$ For the distinction between markets and hierarchies see, OLIVER E. WILLIAMSON, MARKETS AND HIERARCHIES: ANALYSIS AND ANTITRUST IMPLICATIONS: A STUDY IN THE ECONOMICS OF INTERNAL Organization, (Free Press, 1975); Oliver E. Williamson, The Mechanisms of Governance (Oxford Univ. Press, 1996).
} 
often led the Commission to decide not to impose any fine or a remedy. This demonstrates the interaction between remedies and the nature of competition law violations.

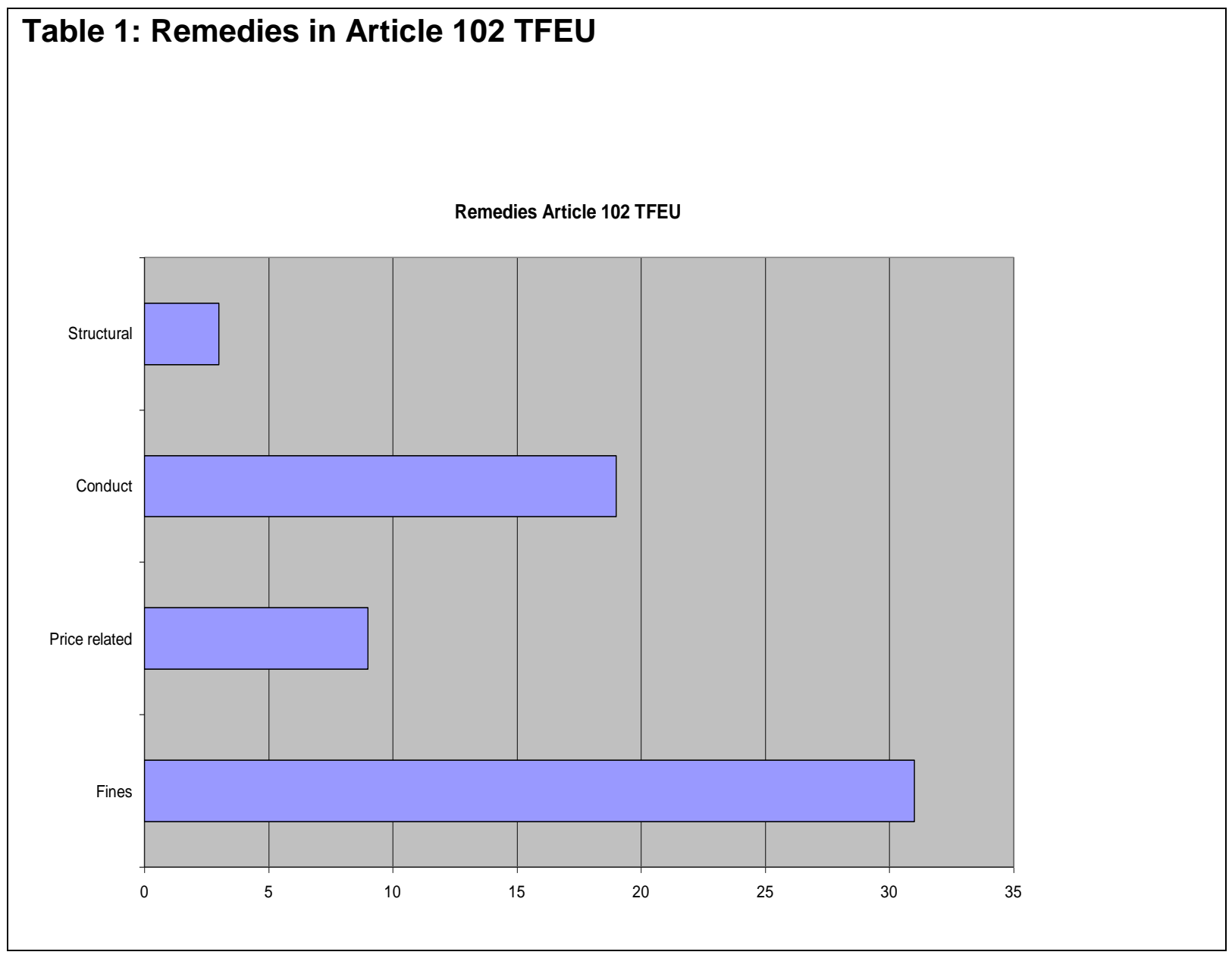

Conduct remedies may take different forms. A constant feature is that, in most cases, they respond directly to the nature of the competition law violation. A refusal to deal/license case often involves as a remedy an obligation to supply or to license. Price discrimination, selective price cutting or predatory pricing claims are often dealt with an obligation to ensure that prices are justified by objective considerations and by an injunction to stop practicing discriminatory, selective or predatory prices. Exclusive dealing and tying claims might lead to conduct remedies that are more intrusive, in the sense that they affect the product or the contractual design. In some cases the Commission has also imposed divestiture remedies. In cases involving loyalty rebates the Commission and the Courts have essentially imposed fines. Presumably the companies would not be able to use the exact rebate scheme that 
was found illegal. The choice of fines over other conduct remedies might be influenced by deterrence reasons and the difficulty to decide remedial schemes that might affect the commercial freedom of the undertakings in their pricing decisions, in particular as the criteria for defining what constitutes a loyalty rebate have been unclear, at least before the publication by the Commission of its guidance on its enforcement priorities under Article 102 TFEU. ${ }^{64}$

However in a number of cases, the Commission has moved further than just adopting conduct remedies mirroring the abuse. The remedies attempt to engineer some form of market or product design. Prophylactic measures imposed to dominant undertakings include the implementation of broad competition law compliance programs, the duty to refrain not only from practices that were found abusive but also from any measure that would adversely affect the competitive position of their competitors, the imposition of a duty to release capacity on the market (see Annex).

This trend is particularly clear in the second Microsoft case. ${ }^{65}$ Following complaints in December 2007 by Opera, the Norwegian Internet browser maker, the Commission alleged a violation by Microsoft of Article 102 TFEU for tying its web browser Internet Explorer to its dominant client PC operating system, Windows. On 16 December 2009 the Commission accepted Microsoft's commitments. ${ }^{66}$ Microsoft committed to (i) distribute a "choices screen' through software update ${ }^{67}$ to European users of Windows XP, Windows Vista, Windows 7, and Windows client PC operating systems, and (ii) allow both OEMs and users to turn on or off Internet Explorer. ${ }^{68}$ The choices screen will give those users who have set Internet Explorer as their default web browser an opportunity to choose whether to install (and which) competing web

\footnotetext{
${ }^{64}$ Communication from the Commission, Guidance on the Commission's Enforcement Priorities in Applying Article 82 EC Treaty to Abusive Exclusionary Conduct by Dominant Undertakings [2009] OJ C 45/7.

${ }^{65}$ For a discussion see, Economides \& Lianos, supra note 1.

66 See Commission Decision, Case COMP/C-3/39.530, Microsoft (Dec. 16, 2009), available at http://ec.europa.eu/competition/antitrust/cases/decisions/39530/final decision en.pdf (hereinafter EU "Microsoft II decision"); Microsoft's commitments are included in the Annex of the Commission's decision (hereinafter "Commitment"). Microsoft made additional commitments on interoperability between rivals' software and its own, including Windows, Windows Server, Office, Exchange, and SharePoint.

67 The screen will allow each consumer to set the default browser of their choice and allow the consumer to uninstall Internet Explorer.

${ }_{68}$ Press Release, Microsoft, Annex A (July 24, 2009), available at http://www.microsoft.com/presspass/presskits/eu-msft/docs/ANNEX A.doc (detailing how this will be implemented in Windows 7).
} 
browser(s) in addition to the one(s) they already have. ${ }^{69}$ Users will be able to select one or more of the web browsers offered through the choices screen. Microsoft has committed to distribute and install the choices screen software update "in a manner that is designed to bring about installation of this update at a rate that is as least as high as that for the most recent version of Internet Explorer offered via Windows Update."70

This remedy does not correspond to the consumer harm story that the Commission advanced in this case. The Commission relied on the relatively favourable case law on tying which establishes a form of quasi per se illegality treatment under Article 102 TFEU if a company has a dominant position. However, the "must carry" commitment accepted by the Commission as an adequate remedy for the competition problem does not address directly this particular risk of abuse. Unbundling would seem to be the most appropriate remedy for a tying concern based on leveraging. However, the Commission reacted negatively when Microsoft decided to unbundle IE from Windows 7-E. ${ }^{71}$ The "must carry" remedy which was ultimately adopted fits better with an essential facilities case, where Windows would have been considered indispensable for the distribution of an Internet browser.

This apparent lack of logical coherence between the remedy adopted and the theory of harm might be justified if one takes a position close to that of discretionary remedialism. But this is not without affecting the nature of the primary right and consequently the scope of the antitrust liability of the dominant firm that is delimited by the theory of harm. The risk of strategic litigation is also present if plaintiffs could employ theories of harm that are easy to prove (because of particular presumptions) in order to achieve the most far reaching remedies, in terms of commitments from a dominant firm. Discretionary remedialism should thus give way to some form of

69 Press Release, Microsoft, Proposed Commitment If 8 (July 24, 2009), available at http://www.microsoft.com/presspass/presskits/eu-mstt/docs/07-24-09Commitment.doc.

${ }^{70}$ ld. at 99.

${ }^{71}$ Matthew Newman, Microsoft is Said to be in Talks to Settle EU Cases, BLOOMBERG, July 7, 2009, available at http://www.bloomberg.com/apps/news?pid=newsarchive\&sid=abzAzMCoi3Rw. Microsoft intended to produce and distribute in Europe solely a special edition of Windows 7 called Windows 7 E which would not have Internet Explorer or any other browser pre-installed, adopting the removal approach of the Windows XP N remedy imposed by the Commission in the first Microsoft case, as the sole version of Windows in Europe. See Commission Decision Case COMP/C-3/37.792-Microsoft [2007] OJ L32/23. 
logical (causal) connection between the remedy and liability, without, however that leading to collapse the two legal categories to one. The principle of remedial proportionality provides a useful compromise between these two positions.

\section{The Need for a Principle of Remedial Proportionality}

The principle of proportionality constitutes an important limit to the European Commission's discretion in imposing remedies. ${ }^{72}$ The principle is included in Article 49(3) of the Charter of Fundamental Rights of the EU providing that "the severity of penalties must not be disproportionate to the criminal offence." It is explicitly provided in Article 7 of Regulation 1/2003 that the Commission may impose on undertakings any behavioral or structural remedies which are proportionate to the infringement committed and necessary to bring the infringement effectively to an end. This provision mainly codifies previous case law of the Court relying on Article $3(1)$ of Regulation 17/62 that the remedies imposed should "not exceed what is appropriate' and should be 'necessary to attain the objective sought, namely [to restore] compliance with the rules infringed. ${ }^{.73}$ Structural remedies are generally not favoured, if there is no equally effective behavioral remedy or where any equally effective behavioral remedy would be more burdensome for the undertaking concerned, as otherwise the remedy might be disproportional. The principle of proportionality takes an arithmetic form in Article 23(2) of the Regulation providing that the Commission may impose fines on undertakings that may not exceed 10 per cent of its total turnover in the preceding business year (an attempt by the legislator to draw a rough balance between the anticompetitive harm and the harm to the undertaking's financial position). In addition, in fixing the amount of the fine, regard

\footnotetext{
${ }^{72}$ See also, Wils, supra note 36 W P.J., 'Optimal Antitrust Fines: Theory and Practice' (2006) 29(2) World Competition 183-208, (noting that "'the principle of proportionality of penalties reflects the retributive view of punishment. Indeed, the utilitarian conception of punishment, which justifies fines being set at the level required for optimal deterrence at the lowest cost, competes for the allegiance of the legal system with the retributive view of punishment. Under the latter view, punishment is not justified by its future consequence of deterring harmful conduct, but rather on the ground that it is morally fitting that a person who does wrong should suffer in proportion to his wrongdoing"').

${ }^{73}$ See Case T-170/06, Alrosa Co. Ltd v. Commission [2007] ECR II-2601, para. 102; Case T-338/94, Finnboard [1998] ECR II-1617, para. 242; Case T-76/89, RTE and ITP v. Commission [1991] ECR li757, para. 93; Case T-7/93 Langnese-Iglo v. Commission [1995] ECR II-1533, para. 209; Case T-9/93 Schöller v. Commission [1995] ECR II-1611, para. 163.
} 
shall be had both to the gravity and to the duration of the infringement as well as to the effect of the competition law infringement on the market. ${ }^{74}$

The General Court (previously Court of First Instance) has also recently applied the principle of proportionality to commitment decisions adopted under Article 9 of Regulation 1/2003: In Alrosa, the Court held that "the voluntary nature of the commitments . . . does not relieve the Commission of the need to comply with the principle of proportionality, because it is the Commission's decision which makes those commitments binding" and that "giving that commitment, the undertakings concerned merely assented, for their own reasons, to a decision which the Commission was empowered to adopt unilaterally." 75 The Commission is subject to the same duty of applying the principle of proportionality in adopting Article 7 or 9 decisions, which would require, in the case of Article 9 "an appraisal in concreto of the viability of those intermediate solutions," that were not finally chosen by the Commission. ${ }^{76}$ However, in a recent judgement, the Court of Justice of the EU (Court of Justice) struck down the judgement of the General Court for having applied the same level of proportionality control to Article 9 and to Article 7 decisions. ${ }^{77}$ The Court of Justice noted that "the obligation on the Commission to ensure that the principle of proportionality is observed has a different extent and content, depending on whether it is considered in relation to the former or the latter article."78

The principle of proportionality is given a specific content in Article 7 of Regulation $1 / 2003$ and in the competition law case law of the European courts. ${ }^{79}$ It requires that

measures adopted by Community institutions do not exceed the limits of what is appropriate and necessary in order to attain the legitimate objectives pursued by the legislation in question; when there is a choice between several

\footnotetext{
${ }^{74}$ See Joined Cases C-189/02 P, C-202 P, C-205-208/02 P, C-213/02 P, Dansk Rørindustry and others [2005] ECR I-5425, para. 243.

${ }^{75}$ Case T-170/06, Alrosa v. Commission [2007] ECR II-2601, paras. 105-6; Appeal Case C-441/07 P.

${ }^{76}$ Id. at para. 156. See, however, the contrary position of Advocate General Kokkott in Case C-441/07 $\mathrm{P}$, Commission v. Alrosa, para. 62.

${ }_{77}^{7}$ Case C-441/07, European Commission v. Alrosa Company Ltd. [June 29, 2010], nyr.

${ }^{78}$ Id. at paras. 38, 48 (noting the specific characteristics of the mechanisms provided for in Articles 7 and 9 of Regulation 1/2003 and the voluntary character of the commitments under Article 9).

${ }^{79}$ Case T-260/94, Air Inter v. Commission [1997] ECR II-997; Case T-65/98, Van den Bergh Foods v. Commission [2003] ECR II-4653, para. 201; Case T-170/06, Alrosa v. Commission, para. 98.
} 
appropriate measures, recourse must be had to the least onerous, and the disadvantages caused must not be disproportionate to the aims pursued. ${ }^{80}$

Proportionality is also a general principle of Community law, applying as such to all measures adopted by Community institutions. According to settled case law,

by virtue of that principle, the lawfulness of the prohibition of an economic activity is subject to the condition that the prohibitory measures are appropriate and necessary in order to achieve the objectives legitimately pursued by the legislation in question; when there is a choice between several appropriate measures recourse must be had to the least onerous, and the disadvantages caused must not be disproportionate to the aims pursued. ${ }^{81}$

This three-part test has, of course, to take into account the margin of discretion of the European Commission in adopting appropriate remedies. In that sense, proportionality differs from a cost-benefit analysis which would focus only on the gravity of harm and the alternative remedies that might have been imposed. That is, the remedy will be disproportionate when its costs and burdens outweigh its likely benefit of restoring competition or when its costs would be more important than an alternative remedy which would have also been equally effective. Proportionality may take into account other issues, such as the degree of judicial deference to the Commission's decision, as "the appropriateness of and the need for the contested decision must be assessed in relation to the aim pursued by the institution." 82 Although the principle of remedial proportionality does not exist as such in US antitrust law, a constitutional proportionality requirement applies to most punitive damages cases as well as to other types of remedies. ${ }^{83}$

The first step of the proportionality principle is of particular interest for our purposes. It may indeed be advanced that the appropriate and necessary character

\footnotetext{
${ }^{80}$ Opinion of Advocate general Kokkott in Case C-441/07 P, para. 46.

${ }^{81}$ Case C-331/88, The Queen v. Minister of Agriculture, Fisheries and Food and Secretary of State for Health, ex parte: Fedesa and others [1990] ECR I-4023, para. 13.

${ }^{82}$ Case T-170/06, Alrosa v. Commission, para. 99.

83 Tracy A. Thomas, Proportionality and the Supreme Court's Jurisprudence of Remedies, 59 Hastings L.J. 73 (2007); E. ThOMAS Sullivan \& RichaRd S. Frase, Proportionality PRINCIPLES IN AMERICAN LAW: CONTROLLING EXCESSIVE GOVERNMENT ACTIONS, (Oxford University Press, 2008). See also, State Farm Mut. Auto. Ins. Co. v. Campbell et al., 538 U.S. 408 (2003) where the US Supreme Court has declined to adopt a strict ratio test for punitive damages, but has suggested that the punitive to actual ratio should rarely be in double digits (i.e., exceed a 9-1 ratio).
} 
of the remedies to be imposed would require a precise remedial measurement, not only with regard to the magnitude and scope (amount) of the harm to consumers/competition or the nature of the infringement, but also in relation to the type of violation that was identified. This might cover a specific competition law category (ie a refusal to deal, a tying case, an exclusive dealing case), ${ }^{84}$ but also the theory of harm advanced in the specific case (ie maintenance of monopoly, leveraging, essential facilities). The importance of remedial fit is often stressed by antitrust law literature. ${ }^{85}$ It is also indirectly linked with the existence of a causal relation between the undertaking's conduct and the theory of harm advanced, which has, as the DC Circuit held in the US Microsoft case "more purchase in connection with the appropriate remedy issue." ${ }^{86}$

Remedies should of course be effective. Their aim would be "to re-establish the competitive situation, i.e., the competitive process that would have prevailed but for the infringement." ${ }^{\prime 87}$ However, it is also clear that the principle of proportionality requires a close fit between the harm and the remedy. Suggestions that remedies may go beyond "mirroring the abuse" profoundly misunderstand the relation between the remedy and the right it is attempting to protect. ${ }^{88}$

A strong approach of discretionary remedialism conceives the primary right as being distinct from the provision of the remedies for violation of that right. There is a dichotomy between rights and remedies, each concept being conceptually isolated from the other. This formalistic position might lead to impose no remedies for the infringement of a right or to impose stricter remedies than the nature and effect of the violation of the right would have required. For example, a remedy that would go

\footnotetext{
${ }^{84}$ On the importance of categorization in the context of Article $82 \mathrm{EC}$, see loannis Lianos, Categorical Thinking in Competition Law and the "Effects-based" Approach in Article 82 EC, in ARTICLE 82 EC: REFLECTIONS ON ITS RECENT EVOLUTION (Ariel Ezrachi ed., Hart Publishing, 2009).

${ }^{85}$ See Thomas O. Barnett, Section 2 Remedies: What to do after catching the Tiger by the Tail 76 Antitrust L.J. 31, 36 (2009) ("the remedy needs to be tied closely to the anticompetitive conduct occasioning it. That means that remedies need to be sufficient, but not overbroad, and proportional to the offense"); Gregory J. Werden, Remedies for Exclusionary Conduct Should Protect and Preserve the Competitive Process, (2009) 76 Antitrust L.J. 65, 65 (2009), "[r]emedies for exclusionary conduct should arise 'organically out of the theory of the case"' (citing LAWRENCE A. SULLIVAN, HANDBOOK OF THE LAW OF ANTITRUST 146 (1977)).

${ }^{86}$ Microsoft, 253 F.3d at 80.

${ }^{87}$ Per Hellström, Frank Maier-Rigaud \& Friedrich W. Bulst, Remedies in European Antitrust Law, 76 Antitrust L.J. 43, 58 (2009).

${ }^{88}$ Id. at 59 .
} 
beyond simply "mirroring the abuse" and would "give the infringer's competitors an advantage over the infringer in order to restore the competitive process" ${ }^{89}$ fixes a high remedial target that might go beyond the violation of the right, the alleged abuse. It could eventually jeopardize the dominant position of the firm, as this is an anomaly to the competitive process, the dominant firm having the ability to behave independently from its competitors. However, Article 102 TFEU does not condemn a dominant position as such, nor does it restrict a dominant firm's ability to compete on the merits. That is, a situation that has not been qualified as an abuse. ${ }^{90}$ Remedies that go beyond mirroring the specific abuse could certainly be adopted in theory but that should be done either by advancing an additional theory of harm/liability under Article 102 that is more directly linked to the remedy sought or by employing a competition law instrument other than Article $102 .^{91}$

An alternative view would be to consider that rights and remedies are profoundly interlinked with each other, so that the remedy is the measure of the right. This profoundly legal realist view would consider that "the nature of the remedy sought in an antitrust case is often an important clue to the soundness of the antitrust claim"92 (the "if you cannot fix it, it isn't broken" argument). Between these two poles, there is the principle of remedial proportionality. Without adopting a strict dichotomy between the identification of the right (or the liability step) and the remedy, the principle of proportionality requires a close link between the two. In an economically informed Article 102 this would require a fit between the theory of harm or the type of abuse and the remedy imposed.

This is certainly the position adopted by the General Court in its Alrosa decision. The Court held that

\footnotetext{
${ }^{89} / d$.

${ }^{90}$ Id. The authors' reasoning is based on an internal contradiction. They advance that remedies may go beyond mirroring the abuse but at the same time they qualify their statement by recognizing that the remedy "should not undermine the infringer's incentive to compete on the merits." However, this is not very different from advancing that the remedy should mirror the abuse. Indeed, if the dominant firm competes on the merits, there is no abuse.

${ }^{91}$ A broader theory of abuse (and consumer harm) under Article 102 TFEU that would have a direct link with the remedies sought could be one option to deal with the problem in this case. Sector inquiries with the possibility of imposing effective remedies, market investigation references or a provision equivalent to 5 of the FTC Act could also be adequate tools.

92 Brunswick Corp. v. Riegel Textile Corp, 752 F.2d 261, 267 (7th Cir. 1984).
} 
compliance with the principle of proportionality requires that, when measures that are less onerous than those it proposes to make binding exist, and are known by it, the Commission should examine whether those measures are capable of addressing the concerns which justify its action before it adopts, in the event of their proving unsuitable, the more onerous approach. ${ }^{93}$

The Commission cannot prohibit "absolutely any future trading relations between two undertakings unless such a decision is necessary to re-establish the situation which existed prior to the infringement." "It is only in "exceptional circumstances" such as "where the undertakings concerned have a collective dominant position," that the Commission may prohibit undertakings completely and indefinitely from contracting amongst each other. ${ }^{95}$ The Court thus found that, in the absence of these exceptional circumstances, the Commission's decision to require from undertakings to refrain for an indefinite period all direct or indirect trading relations between them infringes the principle of proportionality. In this case, the Commission imposed a complete and indefinite cessation of trading relations between Alrosa, a Russian diamond supplier and De Beers, a dominant undertaking on the markets downstream from the market for the supply of rough diamonds. The Commission feared that the exclusive supply commitment laid down in the agreement signed between Alrosa and De Beers would result in strengthening De Beers' market power by excluding Alrosa from the market for the supply of rough diamonds and, consequently, depriving other purchasers of access to the significant source of supply which it represented. The Commission found that imposing this termination to the contractual relation between the two parties was clearly necessary in order to allow third parties to have access to Alrosa's output and to allow Alrosa to compete fully with De Beers. The main concern was that De Beers benefited from an advantage over its competitors, not only because of its size but also because it was able to guarantee the best consistency in the supply of rough diamonds to its customers. This was based on De Beers having access to the output of a larger number of different mines producing a larger variety of rough diamonds being the only producer keeping large stocks. ${ }^{96}$ It was not, however, clear how the imposed

\footnotetext{
${ }^{93}$ Case T-170/06, Alrosa v. Commission, para. 131.

94 Id. at para. 103.

95 Id. at para. 141.

${ }^{96}$ Id. at para. 145 (referring to point 70 of the statement of objections sent by the Commission).
} 
remedy responded to the competition concern raised. First, the Commission had not explained how continuing supply to De Beers would affect Alrosa's ability to guarantee a regular supply of significant quantities of rough diamonds. Second, even if this had been the case, and the continuation of the supply would have increased the competitive advantage of De Beers, thus contributing to maintain or reinforce its dominant position on the market, this does not constitute an abuse of a dominant position. As it is put clearly by the Court:

[s]ince the object of Article [102 TFEU] is not to prohibit the holding of dominant positions but solely to put an end to their abuse, the Commission cannot require an undertaking in a dominant position to refrain from making purchases which allow it to maintain or to strengthen its position on the market, if that undertaking does not, in so doing, resort to methods which are incompatible with the competition rules. While special responsibilities are incumbent on an undertaking which occupies such a position. ${ }^{97}$

As noted earlier, the judgement of the General Court was set aside by theCourt of Justice, mainly for applying the same standard of proportionality to Article 7 and 9 decisions. Interpreted as such, the judgement of the Court of Justice may be limited to Article 9 decisions, thus not denying to the General Court the possibility to subject Article 7 decisions to a strict proportionality test. However, there is also some language in the Court of Justice's judgement that might constrain the ability of the General Court to perform a thorough analysis of the substantive proportionality of the remedy and its fit to the liability theory advanced: the General Court should in no case put forward its own assessment of complex economic circumstances and should not substitute its own assessment for that of the Commission. ${ }^{98}$ The Commission may therefore enjoy a wide remedial discretion by being able to find cover behind the nebulous and still indetermined concept of complex economic assessment, and thus avoid a strict proportionality control of its remedial action. Although one could accept that commitment decisions are subject to less intensive review standards, simply because of their voluntary, almost contractual, nature, such

\footnotetext{
${ }^{97}$ Id. at para. 146 .

${ }^{98}$ Case C-441/07, European Commission v. Alrosa Company Ltd. [29 June 2010], nyr, para. 67.
} 
an approach will not be optimal with regard to final decisions reached by the competition authorities. It remains to be seen if the Court of Justice's approach will extend to Article 7 decisions.

The greater incursion of courts to the remedial discretion of competition authorities cannot only be observed in the enforcement of EU competition law but affects also the application of national competition law. In some recent decisions, the UK Competition Appeal Tribunal (CAT) has performed an assessment of the proportionality of the remedies imposed by the Competition Commission in a number of market investigation reference decisions, under Part IV of the Enterprise Act of 2002. In Tesco Plc v. Competition Commission, ${ }^{99}$ the CAT required the Competition Commission to perform a 'double proportionality' test:

the more important a particular factor seems likely to be in the overall proportionality assessment, or the more intrusive, uncertain in its effect, or wide-reaching a proposed remedy is likely to prove, the more detailed or deeper the investigation of the factor in question may need to be. ${ }^{100}$

The application of this test presupposes that courts might eventually need to go beyond rationality to enquire further into the weight attached to the relevant considerations. The CAT is explicitly linking the remedy with the consideration of the "adverse effect on competition" (AEC) through the means of a proportionality test. The principles of this test are set as following:

the measure: (1) must be effective to achieve the legitimate aim in question (appropriate), (2) must be no more onerous than is required to achieve that aim (necessary), (3) must be the least onerous, if there is a choice of equally effective measures, and (4) in any event must not produce adverse effects which are disproportionate to the aim pursued. ${ }^{101}$

The methodology employed for this analysis is not, however, clearly explained by the CAT, which acknowledges that "the application of these principles is not an exact science." 102 What we have is a general reference to a "balancing exercise between

\footnotetext{
99 Tesco Plc v. Competition Commission, [2009] CAT 6, at para. 139.

100 Id. at para. 139.

101 Id. at para. 137.

102 Id. at para. 138.
} 
the (achievable) aims of the proposed measure on the one side, and any adverse effects it may produce on the other side." 103 The aim is of course to preserve the margin of appreciation of the competition authority as to the methodology employed 'in order to investigate and estimate the various factors which fall to be considered in a proportionality analysis', the Competition Commission, in this case, having the discretion to "tailor its investigation of any specific factor to the circumstances of the case and follow such procedures as it considers appropriate." ${ }^{104}$

In subsequent cases, the CAT performed an intensive analysis of the assessment performed by national competition authorities of the proportionality of the remedy. In Barclays Bank Plc v. Competition Commission the CAT observed that "double proportionality" is not a new legal principle but

simply a convenient label for the common sense proposition that, within a wide margin of appreciation, the depth and sophistication of analysis called for in relation to any particular relevant aspect of the inquiry needs to be tailored to the importance or gravity of the issue within the general context of the Commission's task. ${ }^{105}$

The CAT noted, with regard to the extent of the judicial review exercised by the Tribunal that

[s]o far as concerns evidence, the important distinction is between a decision based upon no evidence, with which the Tribunal may interfere, and one based upon the weight given to particular evidence, which is a matter for the Commission, and with which the Tribunal should not interfere, in the absence of irrationality. ${ }^{106}$

The Tribunal considered also that "fashioning of an effective, reasonable and practicable remedy requires not merely fact-finding about the market as it is, but analysis as to the probable effect of alternative remedies upon that market in the future," which "calls for (inter alia) quantification, evaluation and the analysis of

\footnotetext{
${ }^{103} / d$.

104 Id. at para. 139.

${ }_{105}$ Barclays Bank PIc v. Competition Commission [2009] CAT 27, para. 21.

${ }^{106}$ Id. at para. 23.
} 
causation, sensitivity and risk." ${ }^{107}$ According to the Tribunal, "[t]he relevant failing must satisfy a materiality test", which "will require the finding or decision to be quashed unless the Tribunal is satisfied that a reasonable decision-maker in the position of the Commission would still have reached the same finding or decision."108

The Tribunal stroke down part of the Competition Commission's analysis of adequate remedies for lack of proportionality, finding that the economic methodology employed by the Commission was defective and that in conjunction with the other failings of the decision should lead to its quashing.

In its most recent decision, BAA Limited v. Competition Commission, the CAT seems to have backed up from the requirement that the proportionality test should require a precise quantitative analysis of the impact of the remedy, as the first step of a cost benefit analysis that will compare the adverse effects on competition with the costs of implementing the remedy and its impact on the undertakings. ${ }^{109}$ Even in the absence of a quantitative assessment, the requirement of a qualitative analysis of the impact of the remedy, in comparison to the $A E C$, is, however, sufficient to establish the link between the remedy and the wrong, and thus to question the foundations of discretionary remedialism.

\section{Conclusion}

The topic of competition law remedies for abuse of dominant position or monopolization has not attracted sufficient attention from competition law scholarship in both sides of the Atlantic. ${ }^{110}$ There is an important difficulty in devising a coherent theory of competition law remedies that would accommodate the discretion that the European Commission or the national competition authorities traditionally enjoy in

\footnotetext{
107 Id. at para. 26.

108 Id. at para. 28.

109 BAA Limited v. Competition Commission [2009] CAT 35, para. 261. The Commission does not refer to the requirement of quantification in the Barclays decision.

${ }^{110}$ For a useful and broad, compilation of a bibliography on remedies see, Eleanor M. Fox and Paul Sirkis, Antitrust Remedies: Selected Bibliography and Annotations (American Antitrust Institute, Working Paper No. 06-01, 2005), available at http://ssrn.com/abstract=1103601. In Europe, most literature has focused on merger remedies, an area where the Commission has published guidelies: Commission Notice on remedies acceptable under the Council Regulation (EC) No 139/2004 and under Commission Regulation (EC) No 802/2 [2008] OJ C267/1.
} 
this field, while preserving some logical connection between the measure adopted and the competition law issue identified in the liability phase of the decision. The problem is more acute in the new era of the effects-based approach in the enforcement of Article 102 TFEU. An important ingredient of this approach is the identification of a coherent theory of harm that will be subject to the assessment of the decision maker through different analytical steps. ${ }^{111}$ The implications of this move towards an effects-based approach for the selection of remedies and the operation of the proportionality principle have not, however, been adequately examined yet.

An effects-based approach certainly provides fuel to the Commission's discretion, even if a considerable effort is made to create some formalistic safe harbours, such as the price/cost test for loyalty and bundled discounts and predatory pricing abuses that attempt to structure, if not to restrict, the Commission's discretion by bringing within the scope of the prohibition in Article 102 TFEU only practices that exclude "efficient competitors." 112 This study advances the argument, however, that even if the Commission should be recognized as having an important discretion in adopting the most effective remedies, it would be particularly damaging for competition law to lean towards discretionary remedialism. The effect will be even more devastating for the coherence and legitimacy of competition law, in view of the increasing role of private enforcement, in particular if plaintiffs could employ the less demanding, in terms of standard of proof, theory of consumer harm in order to achieve the most far reaching remedies, in terms of commitments from a dominant firm. As is shown by the operation of the proportionality test, logical coherence between the remedy and the wrong is required in EU competition law.

The question that this study has explored is the transformation of the proportionality test in an effects-based approach. Should the proportionality test be limited to the examination of the reasonableness of the measure, or the existence of less restrictive (to the undertaking's freedom of action) ways of achieving the same

\footnotetext{
111 See Lianos, supra note 84.

${ }_{112}$ As it is clear from the recent Intel decision of the Commission, however, "[a]lthough not indispensable for finding an infringement under Article 82 of the Treaty according to the case law," the efficient competitor analysis is only "one possible way of showing whether Intel's rebates and payments were capable of causing or likely to cause anticompetitive foreclosure." See, Case COMP/C-37.990, Intel, Commission Decision para. 925 (May 13, 2009) (summary at 2009 OJ (C227) 13), available at http://ec.europa.eu/competition/antitrust/cases/dec_docs/37990/37990_3581_11.pdf.
} 
purposes? Should the proportionality test include a cost-benefit analysis of the remedy with regard to its purpose, thus integrating to the assessment of the remedy the consideration of the adverse effect on competition? How this ends-benefits proportionality test could operate in the absence of a quantifiable adverse anticompetitive effect? This is particularly problematic in the context of Article 102 TFEU, where the simple likelihood of an anticompetitive effect provides sufficient evidence of an abuse of a dominant position. Would the proportionality test in this case require an analysis of the theory of harm that has been advanced and a correspondence between the theory of harm and the type of remedy imposed? All these are important questions that need further elucidation. The topic of competition law remedies is the next challenge of antitrust law scholarship. 